\title{
The foraging activity of Carpenter bee, Xylocopa fenestrata on the major crops of Eastern Rajasthan, India
}

Ghanshyam Kachhawa, *Santosh Kumar Charan and Pankaj Nagar ${ }^{1}$

\author{
Bee Biodiversity Laboratory, \\ Department of Zoology, \\ University of Rajasthan, JAIPUR, INDIA. \\ ${ }^{1}$ Department of Statistics, \\ University of Rajasthan, JAIPUR, INDIA. \\ ${ }^{*}$ Corresponding Author \\ E-mail : unirajskcharan@gmail.com
}

Received : 01.08.2020; Accepted : 12.10.2020

\begin{abstract}
The foraging activity of Xylocopa fenestrata was studied for analyzing its role in the pollination of plants to enhance crop production in the Chomu tehsil of Rajasthan, India. Xylocopa fenestrata were collected by hand sweeping net and by implanting artificial carpenter bee nests. The foraging activity of Xylocopa fenestrata showed mutualistic relationship with different plant species in the winter season in which Xylocopa fenestrata collected pollens and nectar from the flowers for nutrition and helped the plants in the pollination. Xylocopa fenestrata behaved differently with eight experimental plants on the basis of size, colour and odor of the flowers. It was found that foraging trip was affected by the different time intervals of the day on the basis of temperature, humidity and wind velocity. Xylocopa fenestrata visited on more flowers and spent least time per flower in the noon to increase foraging trip. It was observed foraging activity was affected by the climatic factors and flower characters. Statistical data analysis by using MS Excel-2019, SPSS version-25 and R-confirmed the significance of experimental result.

$\begin{array}{lll}\text { Figure : } 01 & \text { References : } 20 & \text { Tables : } 04\end{array}$

KEY WORDS : Carpenter bee, Fabricius, Foraging activity, Xylocopa fenestrata
\end{abstract}

\section{Introduction}

Pollination is a process of transferring pollen grains from anther of stamen to the stigma of carpel ${ }^{18}$. Sexual reproduction cannot take place in the flowering plants without pollination. Pollination is essential for the development of fruits and seeds after fertilization in the flowering plants ${ }^{12}$. Some plants are pollinated by means of wind (Anemophily), water (Hydrophilic), birds (Ornithophilic) and many flowering plants are pollinated by the insects, the process is called as Entomophilic pollination. Carpenter bee shows mutualistic relationship with plants ${ }^{16,17}$. By vibrating their wings, insects produce Buzz sound which helps in releasing pollen grains from the anther. Pollen grains fall on the bees which are trapped in the body hairs, the process is called pollen loading ${ }^{2}$. Morphological traits of flowers determine the types of pollinators in the entomophilic plants ${ }^{1,6,15}$. Bees choose their flowers on the basis of inflorescence, colours of flowers, position of flowers on plant, fragrance and sucrose concentration.Flowers allure insects (bees) for their pollination service by charming colours, fragrance and give rewards as pollen and nectar in place. Pollens are rich source of protein while nectar is a rich source of energy. Flight of insects from one plant to another for the course of food collection is known as foraging. Environment of colony affects the foraging activity of bees 5 . Foraging activity is inversely proportional to the amount of pollen grains stored in to the wax comb of the bee colony. Xylocopa fenestrata is considered as a solitary bee but some species like Xylocopa nasalis shares cohabitat in which only one female made nest and foraging and other females guard the nest ${ }^{8}$.It is observed that when the nest is supplemented with brood hormones it enhance foraging activity several times ${ }^{14}$. Environmental temperature, humidity and light intensity affect the foraging activity of bees. Extreme high and low temperatures of environment diminish the foraging activity. High temperature from optimal range negatively affects foraging ${ }^{4}$. Insects show thermoregulations ability in respect to pollination activity ${ }^{9}$.Pollination efficiency is 
TABLE- 1: Experimental plant species and their characteristics

\begin{tabular}{|c|c|c|c|c|c|}
\hline $\begin{array}{l}\text { Plant } \\
\text { species }\end{array}$ & Family & $\begin{array}{l}\text { Flower } \\
\text { size }\end{array}$ & $\begin{array}{l}\text { Floral } \\
\text { symmetry }\end{array}$ & Floral odor & $\begin{array}{l}\text { Floral } \\
\text { colour }\end{array}$ \\
\hline Tagetes erecta & Asteraceae & Large & $\begin{array}{l}\text { Actinomorphic } \\
\text { (In disc) } \\
\text { Zygomorphic } \\
\text { (In florest) }\end{array}$ & Odoriferous & Orange \\
\hline Tagetes patula & Asteraceae & Large & $\begin{array}{l}\text { Actinomorphic } \\
\text { (In disc) } \\
\text { Zygomorphic } \\
\text { (In florest) }\end{array}$ & Odoriferous & Red \\
\hline Brassica campestris & Brassicaceae & Small & Actinomorphic & Mildodoriferous & Yellow \\
\hline Erica sativa & Brassicaceae & Small & Actinomorphic & Mildodoriferous & Yellow \\
\hline Calotropis procera & Asclepiadaceae & Medium & Actinomorphic & Mildodoriferous & Purple \\
\hline Brassica nigra & Brassicaceae & Small & Actinomorphic & Mildodoriferous & Yellow \\
\hline Pisum sativum & Fabaceae & Medium & Zygomorphic & & White \\
\hline $\begin{array}{l}\text { Parthenium } \\
\text { hysterophours }\end{array}$ & Asteraceae & Small & $\begin{array}{l}\text { Actinomorphic } \\
\text { (In disc) } \\
\text { Zygomorphic } \\
\text { (In florest) }\end{array}$ & Odorless & White \\
\hline
\end{tabular}

directly proportional to the temperature and inversely proportional to wind speed ${ }^{14}$. Light intensity independently can not affect the foraging behavior of bees but it can affect with the combination of temperature ${ }^{15}$. Xylocopa is the genus of carpenter bees. These bees work as carpenter and burrow hard wood for making tunnels for the nesting. Xylocopa name was derived from Greek "xylokopos" meaning wood cutter ${ }^{16}$. Xylocopa can be identified by its principal characteristics as large body size, long marginal cells and loss of stigma but very long pre-stigma. Xylocopa also can be identified by its strong papillate distal part of the wing. All carpenter bees have three sub marginal cells in their fore wing but sometimes first and second cells are partially fused. It shows very specific flying pattern distinct from others. Its thorax is hairy yellow or white. Abdomen is so shiny metallic black without hairs. Male is slightly longer and female is comparatively broad.

\section{Material and Methods}

The experiment was performed in the Chomu tehsil of Jaipur district in Rajasthan, India. The geographical coordinates of Chomu is $27.17^{\circ} \mathrm{N}$ (Latitude) and $75.72^{\circ} \mathrm{E}$ (Longitude) at the altitude about 486 meter. Chomu has local steppe climate and denoted by BSh by the kopper Geiger climate classification .This is a famous cultivated area of Jaipur with an average temperature of $32.9^{\circ}$ Celsius . It is usually calm region with an average wind speed is 6.9 knot $(1 \mathrm{knot}=1.15 \mathrm{MPH}=1.85 \mathrm{KPH})$. Xylocopa fenestrata was selected for experimental work that was identified by the authentic key THE INDIAN SPECIES OF THE GENUS XYLOCOPA LATR. (HYMENOPTERA) by Tsing-Chao Ma, Daw Ttsuen, Hangchow from the Laboratories of the Zoological Survey of India, Indian Museum, Calcutta(presently called Kolkata). Experiment was carried out in the winter season from November 2019 to the beginning of March 2020. Temperature and relative humidity were measured by HTC1 digital instrument, model -LCD Digital Temperature Humidity @@3 which was manufactured by Bully's Company with HTC brand. Wind velocity was estimated by hand anemometer Meco961P digital device 
TABLE- 2: Average no. of visits by the Xylocopa fenestrata

\begin{tabular}{l|c|c|c}
\hline \multirow{2}{*}{ Plant species } & \multicolumn{3}{c}{ Duration } \\
\cline { 2 - 4 } & Before 10 am & Between 10am-3 pm & After 3 pm \\
\hline Tagetes erecta & 4 & 17 & 5 \\
\hline Tagetes patula & 3 & 14 & 4 \\
\hline Brassica campestris & 1 & 9 & 4 \\
\hline Eruca sativa & 1 & 6 & 3 \\
\hline Calotropis procera & 3 & 5 & 1 \\
\hline Brassica nigra & 1 & 6 & 1 \\
\hline Pisum sativum & 1 & 3 & 0 \\
\hline Parthenium hysterophorus & 0 & 2 & 0 \\
\hline
\end{tabular}

manufactured by Meco with the model name-961P. Field photography was taken by the Canon EOS1200D Camera with EFS-18-55mm zoom with model numberCanonDS12649, made in Taiwan. Foraging activity was observed with Olympus Binocular and Xylocopa fenestrata bees were captured by hand sweeping insect net and artificial carpenter bee nest. Xylocopa fenestrata bees were trapped in insect killing bottle with $p$ dichlorobenzene as preserving compound. Bees photos were captured by stereo zoom binocular microscope. Foraging activity was recorded by counting of bees and intensively observed by the binocular. Foraging activity was estimated by the number of visits and average time spent on the flowers of different species of plants. Foraging activity was observed in the morning, noon and afternoon with a definite time interval. The data were collected on alternative days. Foraging activity was studied on the flowers of eight different plant species as listed in Table1. Statistical data analysis were carried out by using MS Excel-2019, SPSS version-25 and R.3.5.3 tools.

\section{Result}

Foraging activity in the Xylocopa fenestrata was estimated on the basis of average number of visits by the bee and time spent on flowers of eight different plant species in different time intervals.

Average number of visits: It was found that number of visits by Xylocopa fenestrata bees were greater in the noon as compared to morning and afternoon. Average temperature in the morning (before $10 \mathrm{am}$ ), noon (10 am $-03 \mathrm{pm}$ ) and afternoon (after $3 \mathrm{pm}$ ) were measured as $15.9^{\circ}, 24^{\circ}$ and $18^{\circ}$ Celsius during the observation months. Foraging activity increased as temperature rose from morning to noon with the increased average number of visits of Xylocopa fenestrata on the flowers. As the temperature decreased afternoon, average number of visits of bees decreased (Table-2). It was observed that average number of visits of bees had the significant relationship with the segments of the day. Foraging activity was not observed in the early morning when flowers were closed. Xylocopa fenestrata showed active foraging trip in the noon when flowers were fully blossomed (Table -2). Average number of visits of Xylocopa fenestrata on the flowers also correlated with colour, size and odor of the flowers. Carpenter bee has trichromatic vision. Xylocopa fenestrata visited highest on Tagetes erecta flowers which were large in size, saffron yellow coloured with pleasant fragrance and least visited on Parthenium hysterophorus because of small, white and odorless flowers. Pisum sativum was found second least visited flower because of cleistogamous flowers which always remained close and able to self fertilize and did not depend on the bees for pollination but few bees visited on Pisum sativum for the nectar collection (Fig.-1). Flowers of Tagetes patula are large enough, colourful and odoriferous than the flowers of Calotropis procera so attracted more Xylocopa fenestrata for the foraging trip. Xylocopa fenestrata visited more to Brassica campestris than Eruca 
TABLE-3: Average time spent/flower (seconds) by the Xylocopa fenestrata on the flowers of different species at different hours from November 2019 to March 2020

\begin{tabular}{l|l|l|l|c|c|c|c|c}
\hline Plant species & $\begin{array}{l}6 \mathrm{AM}- \\
8 \mathrm{AM}\end{array}$ & $\begin{array}{c}8 \mathrm{AM}- \\
10 \mathrm{AM}\end{array}$ & $\begin{array}{c}10 \mathrm{AM}- \\
12 \mathrm{PM}\end{array}$ & $\begin{array}{c}12 \mathrm{PM}- \\
14 \mathrm{PM}\end{array}$ & $\begin{array}{c}14 \mathrm{PM}- \\
16 \mathrm{PM}\end{array}$ & $\begin{array}{c}16 \mathrm{PM}- \\
18 \mathrm{PM}\end{array}$ & Mean & SD \\
\hline Tagetes erecta & 6.02 & 6.30 & 5.80 & 5.70 & 5.55 & 5.05 & 5.74 & 0.43 \\
\hline Tagetes patula & 5.80 & 5.95 & 5.50 & 5.00 & 4.95 & 4.80 & 5.33 & 0.48 \\
\hline Brassica campestris & 5.42 & 5.75 & 4.28 & 4.10 & 4.05 & 3.80 & 4.57 & 0.81 \\
\hline Eruca sativa & 5.20 & 5.40 & 4.20 & 3.50 & 3.48 & 3.20 & 4.16 & 0.94 \\
\hline Calotropis procera & 5.70 & 5.85 & 5.30 & 5.25 & 5.00 & 4.50 & 5.27 & 0.49 \\
\hline Brassica nigra & 5.32 & 5.42 & 4.25 & 3.85 & 3.75 & 3.50 & 4.35 & 0.83 \\
\hline Pisum sativum & 4.90 & 5.05 & 4.00 & 3.50 & 3.20 & 2.85 & 3.92 & 0.90 \\
\hline Parthenium hysterophorus & 3.80 & 4.00 & 3.50 & 3.25 & 3.00 & 2.00 & 3.26 & 0.71 \\
\hline Mean & 5.27 & 5.47 & 4.60 & 4.27 & 4.12 & 3.71 & 4.57 & 0.68 \\
\hline SD & 0.69 & 0.71 & 0.82 & 0.92 & 0.94 & 1.04 & 0.83 & 0.14 \\
\hline
\end{tabular}

sativa and Brassica nigra because of long size of plant and clean yellow colour of flowers.

\section{Average time spent by Xylocopa fenestrata on flowers:}

During foraging activity, Xylocopa fenestrata stayed on flowers for pollen and nectar collection in the course, bees took some time to stay on it. The time was noted in Table-3 as time spent by the carpenter bee per flower in seconds. Xylocopa fenestrata spend more time on the flowers of Tagetes erecta than Tagetes patula and Calotropis procera. It was found that Xylocopa fenestrata stayed more on large, odoriferous and colourful flowers. It was observed that flowers of Tagetes erecta were enough large with attractive colour and fragrance to attract more bees and its flower symmetry zygomorphic in florets favored for pollen collection so Xylocopa fenestrata stayed for more time. These characters of Tagetes erecta increased average time spent for carpenter bees. Tagetes patula flowers were less favored then tagetes erecta by the Xylocopa fenestrata. It was observed that Xylocopa fenestrata spent least time on Parthenium hysterophorus than rest of the experimental plants because of odorless, small sized and white flowers. Pisum sativum had medium sized flowers but was found as cleistogamous flower in which pollen sacs were closed in the petals. Xylocopa fenestrata went on it only for nectar collection so least visited. By observing Table-3, it was found that Calotropis procera attracted more Xylocopa fenestrata for the pollination than Pisum sativum because of dry hollow stems of it which were used by carpenter bees for their nesting. Amongst the flowers of brassica family, Xylocopa fenestrata stayed long on Brassica campestris than Brassica nigra and Eruca sativa. Brassica campestris had clean yellow flowers and enough long stem than Eruca sativa. It was also observed that white flowers of Brassica campestris rarely attracted Xylocopa fenestrata. It was found that this bee did not equally behave with all types of flowers of different plant species.

It was also observed that there was a significant relationship between average times spent by the Xylocopa fenestrata on the same flower and different time intervals of the day. In the morning, when temperature was low with dim sunlight then this bee stayed for the long duration on the flowers. It enhanced average time spent by the bee for a particular flower species. Time spent per flower (in seconds) by the Xylocopa fenestrata decreased continuously after the $10 \mathrm{am}$ to $6 \mathrm{pm}$ with increasing temperature. This was also found significant for all flowers 
TABLE-4: ANOVA Testing for average time spent on flowers and number of visits by the bee

Null Hypothesis 1: The Average-Time, spent by Xylocopa fenestrata on different Flowers, are eqaul. Null Hypothesis 2: The Average-Time, spent by Xylocopa fenestrata on different time intervals, are eqaul.

\begin{tabular}{l|c|c|c|c|c|c}
\hline Source of Variation & SS & df & MS & F & P-value & F crit \\
\hline Plant species & 28.7452 & 7 & 4.10645 & 57.3523 & $2.7 \mathrm{E}-17$ & 2.28524 \\
\hline Dates & 18.5472 & 5 & 3.70943 & 51.8073 & $3.4 \mathrm{E}-15$ & 2.48514 \\
\hline Error & 2.50602 & 35 & 0.0716 & & & \\
\hline Total & 49.7983 & 47 & & & & \\
\hline
\end{tabular}

of different plant species. Statistical data analysis were carried out by using SPSS version-25 and R-3.5.3 resulted that Null Hypothesis cannot be accepted. It means that there is a significant effect of Different Species of Plants and Hours for the time duration of visit of the bee (Table-4).

\section{Discussion}

Foraging activity of Xylocopa fenestrata was found basic need for the survival so bees collected their nutrition from the different plants. As shown in the result that foraging activity was greater at noon as compared to morning and afternoon because environmental condition of noon favored for the foraging that time. It was observed that average temperature was low $\left(15.9^{\circ} \mathrm{C}\right)$, high average relative humidity ( $62.5 \%$ ) and flowers were not fully blossomed in the morning before $10 \mathrm{am}$ in the experimental area. These all factors suppressed the foraging activity in the morning. Temperature alongwith humidity induce anther ripening and helps in releasing of pollens. It was found at the noon (10 am - $3 \mathrm{pm}$ ) that relative humidity decreased as time passed and temperature increased which favored most for foraging activity at the noon. The result was also supported by the previous study on the carpenter bee flight physiology ${ }^{13}$ and temperature regulation in Xylocopa ${ }^{3}$. Every bee requires a specific range of optimal temperature for the foraging activity which was also supported by the study on carpenter bee, Xylocopa sulcatipes ${ }^{7}$. It was observed that wind velocity greatly affected foraging activity in the morning as well as in the noon and afternoon. Average annual wind velocity in the experimental area was estimated $6.9 \mathrm{knot}(1 \mathrm{knot}=1.15 \mathrm{MPH}=1.85 \mathrm{KPH})$ and average wind velocity during the five months of (November19 to March-2020) experiment was measured 3.63 knots. Foraging activity greatly decreased in the heavy wind by decreasing visit per flowers and average time spent per flower. Variation was also observed in the foraging activity of Xylocopa fenestrata in the five experimental months from November-2019 to March-2020 because of variation in climatic condition. It was observed by analyzing the research data that average time spent by the Xylocopa fenestrata on flowers decreased with the increasing number of visits on flower in seconds after morning because as time passed after the morning, temperature raised which made Xylocopa fenestrata more active for foraging trip. It increased number of foraging trips on flowers to rapidly collect pollens and nectar. It was found that flowers of different plant species greatly affected foraging nature of Xylocopa fenestrata because of variations in phenotypic traits like size, colour and odor of different flowers. Xylocopa fenestrata was attracted more towards large sized, colourful and odoriferous flowers that was observed in result.

\section{Conclusion}

Xylocopa fenestrata shows diurnal variation in foraging activity with different time intervals in the day. Foraging activity of Xylocopa fenestrata is affected with climatic factors like temperature, relative humidity, wind velocity and floral characters like size, colour and odor of the flowers. Large sized and odoriferous flowers efficiently attract bees, so should be planted more near the agriculture field for yielding more crop.

\section{References}

1. Baker HG, Hurd PD. Intrafloral ecology - Ann. Rev. Ent. 1968; 13 : 385-414. 


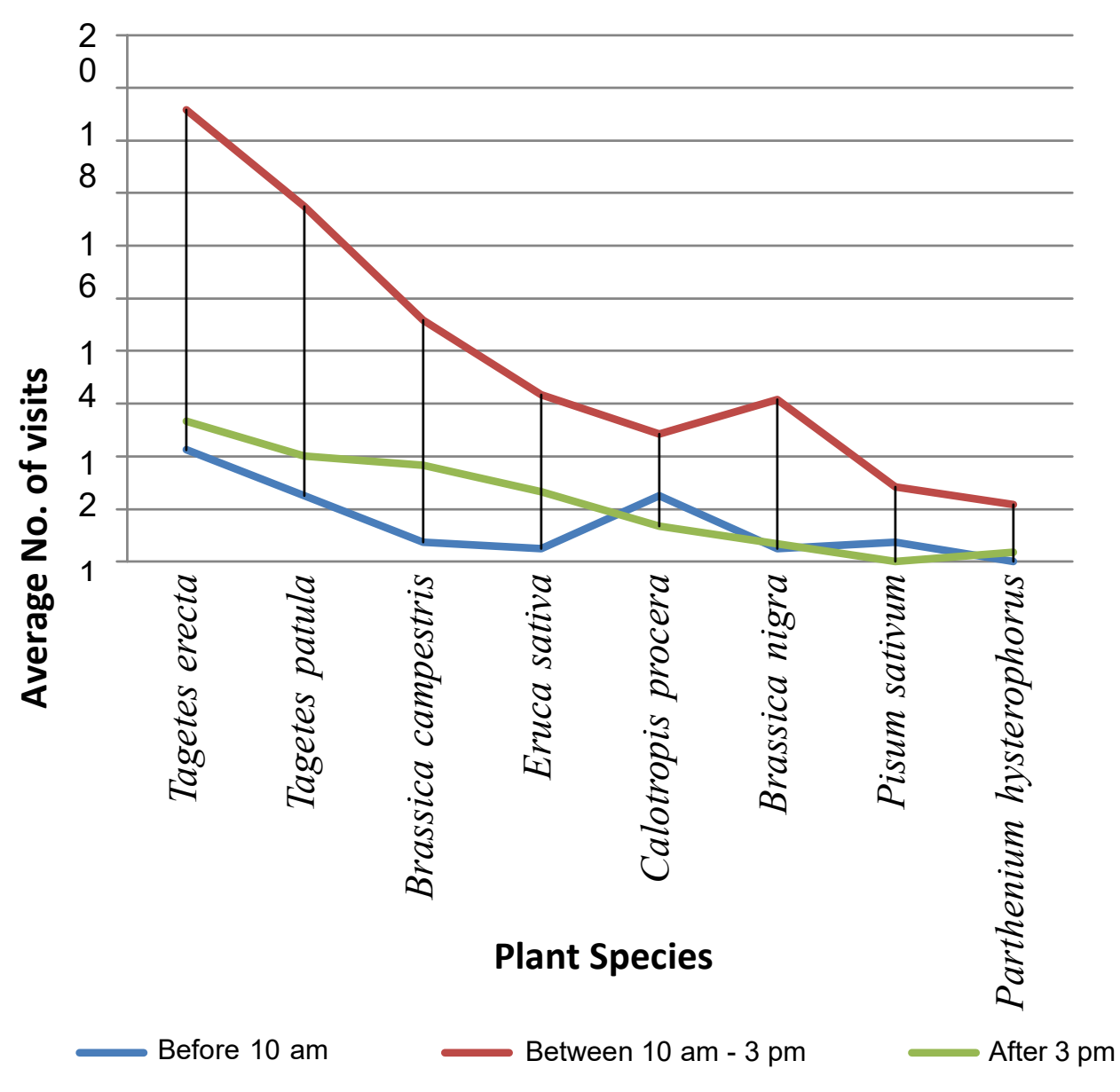

Fig. 1: Average number of visits by Xylocopa fenestrata in different plant species

2. Buchmann SC. Buzz pollination in angiosperms. In Handbook of Experimental Pollination Biology (C.E. Jones, R.J. Little eds.). Van Nostrand Reinhold, New York. 1983; 73-114.

3. Chappell MA. Temperature regulation of carpenter bee (Xylocopa californica) foraging in the Colorado Desert of Southern California. Physiology Zoology. 1982; 55 : 267-280.

4. Cooper PD, Schaffer WM. Temperature regulation of honey bee (Apis mellifera) foraging in the Sonoran Desert. J. Exp. Biol. 1985; 114 : 1-15.

5. Dreller C, Page RE. Genetic, developmental and environmental determinants of honey bee foraging behaviour. 1999; pp.187-202. In C. Detrain, J.L. Deneubourg and J.M. Pasteels (eds.), Information processing in social insects. Birkhauser verlag, Basel, Switzerland.

6. Faegri K, Van der pijl L. The principles of pollination ecology. 3rd ed. - Pergamon, Oxford.1978.

7. Gerling D, HefetzA. The ecology of the Carpenter bee, Xylocopa sulcatipes Maa in Israel. In : Developments in Arid Zone Ecology and Environmental Quality. Ed. H. Shuval. Balaban ISS, Philadelphia. 1981; 71-74.

8. Gerling Dan, Hurd, Paul David, Hefetz, Abraham. Smithsonian contributions to zoology. Smithsonian Institution Press. 1983.

9. Heinrich B. Bumble bee economics - Harvard University Press, Cambridge, MA. 1979(a).

10. Heinrich B. Keeping a cool head : Honey bee thermoregulation Science. 1979(b); 205:1269-1271.

11. Liddell, Henry George, Robert Scott. A Greek - English Lexicon (Abridged Edition) United Kingdom : Oxford University Press. 1980; p.472. ISBN 0-19-910 207-4. 
12. McGregor SE. Insect pollination of cultivated crop plants. Agriculture Handbook No. 496. USDA, ARS, Washington. 1976; 411.

13. Nicolson SW, Louw GN. Simultaneous measurement of evaporative water loss. Oxygen consumption and thorasic temperature during flight in a carpenter bee. Journal of Experimental Zoology. 1982; 222 : 287-296.

14. Pankiw T, Page RE, Fondark MK. Brood pheromone stimulates pollen foraging in honey bees (Apis mellifera). Behav. Ecol. Sociobiol. 1998; 44:193-198.

15. Proctor M, Yeo P. The pollination of flowers - Collins, London. 1973.

16. Scott PE, Stephen L, Buchamann SL, Rourke MKO. Evidence for mutualism between a pollen-piercing carpenter bee and Ocotillo : Use of pollen and nectar by nesting bees. Ecol. Entomol. 1993; 18:234-240.

17. Snow AA, Roubik DW. Pollination deposition and removal by bees visiting tree species in Panama. Biotropica. 1987; 19:57-63.

18. Stern RK. Introductory Plant Biology. Wm. C. Brown Publisher, New York, USA. 1994; 537.

19. Szabo TI, Smith MV. The influence of light intensity and temperature on the activity of alfa alfa leaf cutter bee Megachile rotundata under field conditions; J. Apic. Res.1972; 11 : 157-165.

20. Wrona S. Influence of certain ecological factors on the effectiveness of Melita leporina in pollinating lucernne; Zesz. Probl. Poste Pow Nauk Rolin. 1973; 131 : 167-171. 